\title{
The Library Crisis Management Research
}

\author{
WU Xiao Jun \\ The Engineering \&technical College of Chengdu University of Technology, Leshan, \\ Sichuan, China, 614000 \\ wu_xjun@126.com
}

\begin{abstract}
The modern library in the face of a lot of reality and potential crisis, constructing scientific and effective crisis management model is the key of library crisis management, this article on the basis of the library crisis management system has carried on the detailed planning and design, build a suitable model of library crisis management system, provide the beneficial reference to promote the library management performance.
\end{abstract}

Keywords: library, crisis management, model

\section{Introduction}

In recent years, the disputes about the readers and the library, for example, the national library, Suzhou library events, etc., let's see the library faces the crisis, also brings new challenges to the library management. In uncertain risky society, the crisis is becoming a "normal". Modern library as an important part of society the forehead, also must face many due to the change of internal and external environment formed a threat to its own survival and development of the reality and potential crisis. In this background, only attaches great importance to the various crises faced by modern library, and take various effective measures to the library crisis fell to minimize, to make the modern library to the track of healthy development .

\section{The Definition of Library Crisis Management}

Research on the library crisis management literature at present is relatively small. Due to the concept, personnel, traditional, capital and management concept, the RMB for books of crisis management research in China mainly still stays on the exploration research, the lack of a relatively deep research and practical application. Comprehensive research scholars at home and abroad for the research and analysis of library crisis, this paper in the process of research, the library crisis management is defined as: the library crisis is to point to by some unusual factors both inside and outside the library cause adverse factors of the library, and hinder the normal service function abnormal state.

\section{Build Crisis Management Model}

From the perspective of library crisis incidents in recent years, the happening of the crisis, in the process, all throughout the crisis management strategy formulation, and departments at all levels and media people timely communication and coordination, etc. As the library rights of citizen consciousness gradually improve, the library crisis has gradually come out, including services, human resources crisis, the financial crisis, many aspects, such as the library to survive better, need to prevent the production of various kinds of crisis, through the establishment of reasonable and effective crisis management model in case of crisis, hinders the development of the library.

\subsection{Construction of the library crisis management model system}

Given the similarities in the process of library crisis management and crisis management, in the study, this article constructed the index system of the library crisis management model as follows:

Table 1: The index system of the library crisis management model

\begin{tabular}{|c|c|c|}
\hline \multirow{16}{*}{$\begin{array}{l}\text { The } \\
\text { Index } \\
\text { System } \\
\text { of } \\
\text { Library } \\
\text { Crisis } \\
\text { Manag } \\
\text { ement } \\
\text { Model }\end{array}$} & $\begin{array}{l}\text { Level } \\
\text { indicators }\end{array}$ & The secondary indicators \\
\hline & \multirow{3}{*}{$\begin{array}{l}\text { Crisis } \\
\text { Management } \\
\text { Strategy }\end{array}$} & $\begin{array}{l}\text { Crisis management strategy } \\
\text { formulation }\end{array}$ \\
\hline & & $\begin{array}{l}\text { Crisis management strategy } \\
\text { implementation }\end{array}$ \\
\hline & & $\begin{array}{l}\text { Crisis management strategy } \\
\text { evaluation }\end{array}$ \\
\hline & \multirow{3}{*}{$\begin{array}{l}\text { Crisis } \\
\text { Management } \\
\text { Organization } \\
\text { Structure }\end{array}$} & The library leadership \\
\hline & & $\begin{array}{l}\text { Library to complete the degree } \\
\text { of long-term planning } \\
\text { objectives }\end{array}$ \\
\hline & & $\begin{array}{l}\text { The strain capacity of the } \\
\text { library to the outside world } \\
\text { changes }\end{array}$ \\
\hline & \multirow{3}{*}{ Resources } & The library funds investment \\
\hline & & The library human resources \\
\hline & & $\begin{array}{l}\text { The diversity of library } \\
\text { document carrier }\end{array}$ \\
\hline & \multirow{3}{*}{$\begin{array}{l}\text { Library } \\
\text { Culture }\end{array}$} & $\begin{array}{l}\text { The quantity and quality of the } \\
\text { library written policy }\end{array}$ \\
\hline & & Staff mental outlook \\
\hline & & $\begin{array}{l}\text { The library personalized } \\
\text { service }\end{array}$ \\
\hline & \multirow{3}{*}{$\begin{array}{l}\text { The Crisis } \\
\text { Management } \\
\text { Information } \\
\text { Communicat } \\
\text { ion }\end{array}$} & $\begin{array}{l}\text { External cooperation and } \\
\text { strategic alliance }\end{array}$ \\
\hline & & $\begin{array}{l}\text { The update frequency of } \\
\text { library portal }\end{array}$ \\
\hline & & $\begin{array}{l}\text { With the user communication } \\
\text { and coordination ability }\end{array}$ \\
\hline
\end{tabular}




\subsection{The library crisis management index meaning parsing}

\subsubsection{Crisis Management Strategy}

(1) Strategy formulation. In this paper, we study in the process, the SWOT analysis of the library crisis, so that in view of the situation of the library crisis formulate emergency processing plan. $\mathrm{S}$ is the library available advantage in crisis, $\mathrm{W}$ is the weakness of the library in crisis and defects, $\mathrm{O}$ refers to the library available external environment opportunity in crisis, $\mathrm{T}$ is the library in the external environment facing the threat of crisis management.

(2)Strategy implementation. In the library crisis management in the implementation stage, the library to develop crisis management plans, and combined with a library of related system, insisting that the rights and interests of users in the first place.

(3) Strategic assessment. In crisis strategy evaluation phase, to evaluate the results of strategic management and crisis management, using information gained by the evaluation process to modify and improve the strategy and at the same time, the effectiveness and evaluation of library crisis management and explore a similar crisis better strategy.

\subsubsection{Crisis Management Organization}

Library management organizational structure in our country, and in fact is a tree structure, but according to different crisis that may occur, temporary transfer related staff to form a new library crisis management team, are more likely to succeed than individuals such as curator. Aiming at the crisis management of library crisis management organization, in crisis management, actively mobilize the crisis affairs more familiar with the librarians and the crisis as soon as possible to solve.

\subsubsection{Library Resources Protection}

Library resources protection mainly includes the library funds, human resources, public relations and crisis management information resources preparation, etc. Library funds in proportion to inputs, and set up some public welfare donation system, can effectively make the library work, and timely response to the crisis that may occur. Human resource is one of the important resources of crisis management, crisis management leadership team is the most basic library crisis management and the necessary human resources.

\subsubsection{Library Culture}

The core values of library is to serve, in the daily operation, also need always follow the library culture. Crisis management is one of problems, especially the idea problem, the library crisis management plan if do not conform to the concept of library culture, its effectiveness is extremely limited. The concept of library culture promotion, can help the library under the dynamic environment of highly uncertain continuously updated cognitive style, don't deviate from the original direction, so as to help the library to avoid crisis.

\subsubsection{The Crisis Management Information}

Communication

Effective information communication mainly including communication media and communication subject and to ensure the continuity of communication channels and smooth general characteristic, crisis management experts put forward the famous British $3 \mathrm{~T}$ principle of crisis communication, all the active communication, communication, and communication as soon as possible. Take the initiative communication, means that the library become the main channel of information communication, the reverse of the crisis has a key role. All communication refers to the library to the crisis of the existence of the fact that all tell users, has established a good image, increase the user's trust in the process of service. In the implementation of the communication as soon as possible, the library should not only actively speak the truth, and communicate within the first event, to expand effective stem the crisis. In addition, the library can select and train a specialized public spokesman, ensure the consistency of the inside and outside the library information, establish a good image.

\section{Conclusion}

In the process of building model of library crisis management system, the index system is divided into several elements, thus the influence of the dimension for each indicator weight, can reduce the index set of subjective arbitrariness, enhance the credibility and effectiveness of the model system of crisis management, reduce the relative difficulty of crisis management, improve the standardization of library crisis management, scientific and authenticity. To be sure, the above building of library crisis management model is established on the basis of more common and ideal, in specific applications can modify it according to the actual situation in different areas, in order to improve the efficiency and success rate of library crisis management.

\section{References}

[1] Yu Liang Zhi. Reference, "Expand the social public information space, China's public library sustainable development model in the 21st century" Proc. Science Press, pp. 2004.

[2] He Bao Cheng. Reference, "Introduction to construction of enterprise crisis early warning management system" Proc. Management and Development, pp. 5-6, 2004.

[3] Xu Fang, Jiao Qiu Yang. Reference, "Research of establishing library crisis early-warning management system" Proc. Theory and Practice of Intelligence, $\mathrm{pp}$. 22-25, 2007.

[4] Shen Rong. Reference, "Library crisis and the early warning management model based on data mining research" Proc. Journal of Intelligence Science, pp. 1060-1063, 